\title{
VULNERABILITY OF THE INDUS RIVER DELTA OF THE NORTH ARABIAN SEA, PAKISTAN
}

\author{
KALHORO N.A. ${ }^{1,2,3,{ }^{*}}$ \\ HE Z. ${ }^{1,2}$ \\ $\mathrm{XU} \mathrm{D}^{2,1}$ \\ FAIZ M. ${ }^{4}$ \\ YAFEI L.V. ${ }^{1}$ \\ SOHOO N. ${ }^{3}$ \\ BHUTTO A.H. ${ }^{3}$
}

\author{
${ }^{1}$ Institute of Physical Oceanography, Ocean College \\ Zhejiang University, Hangzhou 310058, China \\ ${ }^{2}$ State Key Laboratory of Satellite Ocean Environment Dynamics \\ Second Institute of Oceanography, State Oceanic Administration, \\ Hangzhou 310012, China \\ ${ }^{3}$ National Institute of Oceanography \\ Karachi75600, Pakistan \\ ${ }^{4}$ Centre of Excellence in Marine Biology \\ University of Karachi 75270, Pakistan
}

Received: 31/01/2016

Accepted: 30/05/2016

Available online: 24/06/2016 *to whom all correspondence should be addressed: e-mail: noorahmed niopk@yahoo.com

\section{ABSTRACT}

Seawater intrusion has been a serious problem in the Indus River Estuary (IRE) for decades. The literature reviews, hydrological and meteorological observations were analyzed to examine and discuss the causes and consequences of seawater intrusion in the IRE. Both sea water intrusion and coastal erosion are having a devastating environmental and social impact and the whole ecosystem of the Indus Delta is facing serious threat. The Indus deltaic region is not only threatened by continuing activities upstream but also by the neighboring sea in the south, due to the impacts of local weather conditions. Observational results suggest that seawater intrusion reaches $84 \mathrm{~km}$ upstream in the IRE during the dry season. Extensive field investigations and a high resolution coastal ocean model are urgently needed for future study.

Keywords: Indus Delta, sea water intrusion, coastal erosion, degradation, future directions

\section{Introduction}

The Indus Delta is located in the southeastern Pakistani coast, with an area of about 600,000 hectares (ha) (Forestry Sector Master Plan, 1992), extending from the Korangi Creek in the north to the Sir Creek in the South along the four southern districts of the Sindh province of Pakistan i.e. Karachi, Thatta, Sujawal and Badin. Its' typical fan shape was created by the discharge of large quantities of silt washed down from the mountain areas which border China, Pakistan, and India. It has about 17 major creeks, innumerable minor creeks, mud flats, and fringing mangrove (Meynell and Qureshi, 1993), as shown in Figure 1. Once all these creeks were once functional but now the active delta is reduced to only $10 \%$ of its original area (ADB Review Report, 2005). At present, only the area between the Hajamro and Kharak Creeks receive water from the Indus, with one main outlet (Khobar Creek) to the sea (Inam et al., 2007). The Indus River Estuary (IRE), with a basin area of about $36 \mathrm{~km}^{2}$, is a bar-built estuary of $40 \mathrm{~km}$ in length, comprising 7 major tributaries i.e. 
Rohro, Mutni, Wadh, Khund and Watho to the southeast and Bhoori and Aado War to the southwest; main channel of the Indus river estuary is called Khobar (Figure 1).

The Indus River is considered one of the largest rivers in Asia with a drainage area of about $950,000 \mathrm{~km}^{2}$. It originates from the Tibetan Plateau near Lake Mansarovar, flows through Ladakh, Gilgit and Baltistan, flows through the entire length of Pakistan and finally merges into the Arabian Sea near the port City of Karachi, in the Sindh Province of Pakistan. The length of the river is of the order of $2880 \mathrm{~km}$ (Abbasi, 2002), while related values in literature can reach 3200 km (Mirovoi, 1974; Milliman et al., 1995).

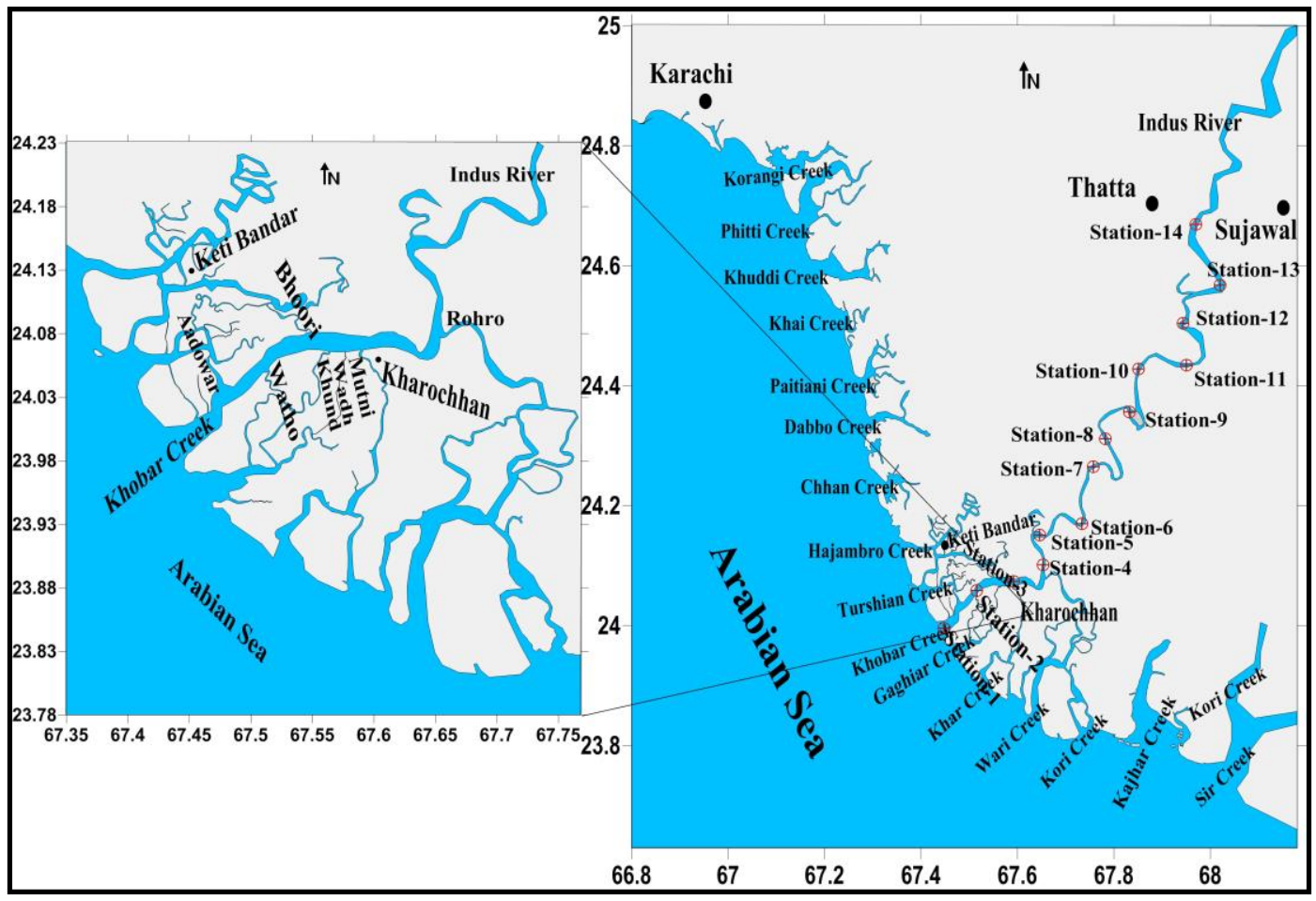

Figure 1. Study area of Lower Indus River with a network of major creeks and tributaries

The Indus River has remained the main source of agriculture, fishing, and trade in Pakistan over centuries. Ships were able to reach the cities of upper Sindh from the sea-port through the river due to its sufficiently high water levels in the past. During this period, it is reported that social and economic conditions in Sindh province were generally good and people were prosperous (Hughes, 1876).

The Indus River was one of the largest sediment providing rivers in the world. Fifty to seventy years ago, it carried 185 BCM (Billion Cubic Meters) of fresh water and about 400 MT (Million Tons) of silt per year to its delta (Wells and Coleman, 1984; Nasir and Akbar, 2012) and was used to support the livelihood of the Indus Delta vicinity. In recent years, the water level of the Indus River has begun to decline due to certain conflicts.

A reported conflict emerged before partition between Sindh and Punjab, during 1941. This dispute was settled in 1945 through the Roy Commission, agreement that was termed the "Sindh-Punjab Agreement". According to this agreement, no construction would be allowed upstream of the river without the consent and approval of Sindh. Later on, Pakistan and India signed the Indus Basin Water Treaty under the auspices of the World Bank. This treaty also proclaimed that, the three eastern rivers, namely Bias, Sutlej and Ravi, came under the control of India while the three western rivers, namely Chenab, Jhelum and Indus, came under the control of Pakistan (Memon, 2004). Moreover, India was also allowed to irrigate 1.3 million acres from western rivers. Following this agreement, the downfall of the Indus River began, as Pakistan also established the Water and 
Power Development Authority, which started diverting the Indus water. Consequently, large dams, reservoirs, barrages, and irrigation systems were constructed.

The abrupt reduction in water and sediment run off in the Indus River below the Kotri barrage has affected the hydrological processes in the river's lower reaches and, at present, its delta is degrading. The reduction in silt load and fresh water to the Arabian Sea has increased the impact of waves and tides and stunted the growth of mangroves, resulting in coastal erosion and seawater intrusion.

The purpose of this paper is to summarize the literature on the impacts, causes, and consequences of sea water intrusion and coastal inundation in the Indus deltaic region and to suggest urgent research directions, which may provide a useful input for sustainable management of the Indus deltaic region and prevent further salinization problems. At the same time, and given the lack of observational field data available in literature, two field surveys were also carried out, during wet and dry seasons, in order to estimate the exact extent of seawater intrusion.

\section{Methodology}

Three approaches were taken for this study; one using in-situ field surveys conducted during wet (fluvial discharge) and dry (zero fluvial discharge) seasons, in order to assess the seasonal variation and exact extent of seawater intrusion in the IRE. Another approach was to obtain meteorological and hydrological data from the Pakistan Meteorological Department and Sindh Irrigation and Drainage Authority, respectively. The third approach was to summarize the published literature on the Indus River Delta. Regarding the field measurements conducted, a longitudinal profile of salinity and suspended sediment concentration (SSC) data was collected during two campaigns, the first of which was conducted on May 2013, when the discharge of the Indus River was at zero level (dry season) and the second campaign took place in August 2014, and was characterized as a wet season (fluvial discharge, $910.18 \mathrm{~m}^{3} \mathrm{~s}^{-1}$ ). Observations were carried out every $7 \mathrm{~km}$ from the river mouth, over a distance of $98 \mathrm{~km}$ on the upstream side and at mid-channel. Surface and bottom water samples were collected at fourteen stations with a $5 \mathrm{~L}$ Niskin bottle to determine the salinity and SSC. SSC was measured by filtering water samples with GF/F $0.7 \mu \mathrm{m}$ filters, which were then oven-dried for $24 \mathrm{~h}$ at $60{ }^{\circ} \mathrm{C}$. Salinity was recorded using a water quality meter (Hydrolab Model MS-5); the salinity sensor of the water quality meter was calibrated using standard saline water.

\section{Results and Discussion}

\subsection{Climate and River flow}

The climate of the Sindh Coast is arid sub-tropical with quite low and irregular precipitation. As shown in Figure 2, the data in the past fifty years obtained from twelve meteorological stations at Sindh province revealed the high interannual variability of precipitation, with drought conditions observed in several of the yearly records. At the same time, the annual flow discharge clearly presents a decline trend. The Thatta (Indus Coast) meteorological station data show that the monthly average precipitation for the past twelve years was as low as $16.40 \mathrm{~mm}$; the records show that nearly zero precipitation was recorded even during the monsoon season (April to September) of specific years, as shown in Figure 3. According to ADB and IUCN (2002), the average annual rainfall in the Sindh coast was $220 \mathrm{~mm}$, whereas the average annual temperature range was between $23.8^{\circ} \mathrm{C}$ and $28.7^{\circ} \mathrm{C}$. It follows that the mangrove forests in the Indus Delta are largely dependent upon the freshwater discharges from the Indus River, as only a meagre amount of freshwater run-off reaches the delta to support the mangrove flora.

According to the monthly and yearly record of the Kotri downstream data, the seasonal and annual river flows in the IRE system are also variable. For instance, Kotri downstream data showed that 155.36 BCM water was 
released in 1959 and $118.77 \mathrm{BCM}$ water with $274 \mathrm{MT}$ of sediment was released during 1973, while the water was only $0.32 \mathrm{BCM}$ with $1 \mathrm{MT}$ of sediment in 2002 (Figure 2). According to monthly records over 15 years, shown in Figure 3, the Indus Delta only receives fresh water during the months of August and September and there is virtually no discharge below the Kotri barrage in the winter months. Although during super flood years a huge amount of water was discharged, such as 112.50 BCM in 1994 and 67.02 BCM in 2010, the delta still remained dry during the rest of the year, because these peak discharges under flood periods were concentrated in short-term periods.

An International Panel of Experts in 2005 advised that $5000 \mathrm{~m}^{3} \mathrm{~s}^{-1}$ should be released daily downstream from Kotri throughout the year, while Sindh demanded an annual 10 MAF (12 BCM) release of water post-Kotri Barrage, under the 1991 Water Accord. According to the Water Accord signed between the Pakistan provinces of Punjab, Sindh, and Balochistan in Pakistan on March 1991, the Indus Delta required more than 12 BCM below Kotri for the survival and maintenance of the deltaic ecosystem.

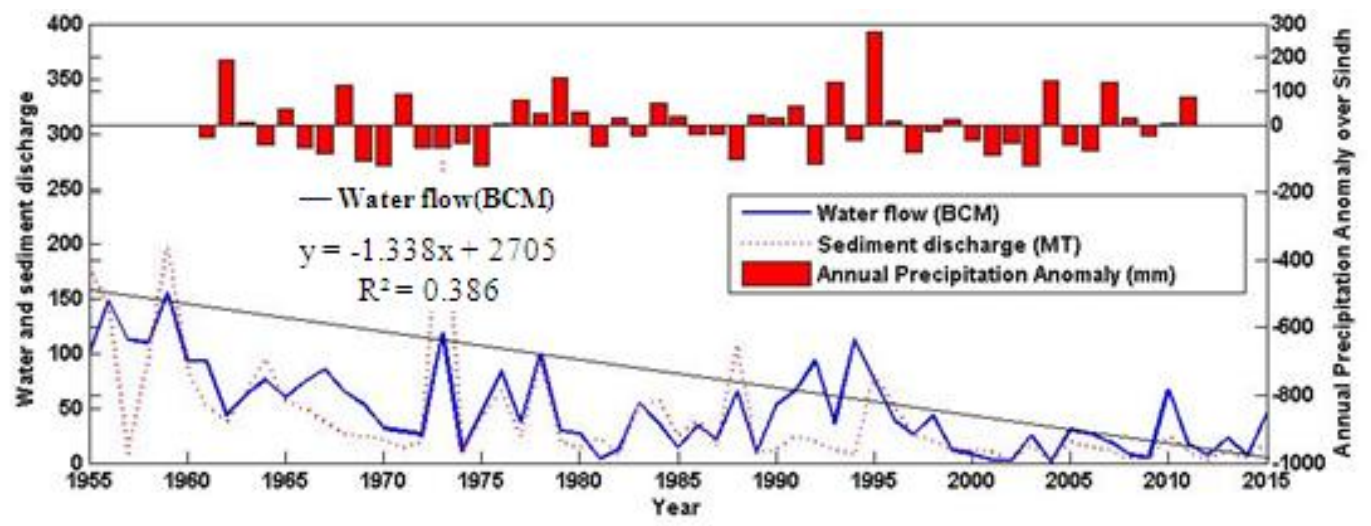

Figure 2. Yearly water and sediment discharge below the Kotri Barrage and annual precipitation anomalies over Sindh showing flood and drought

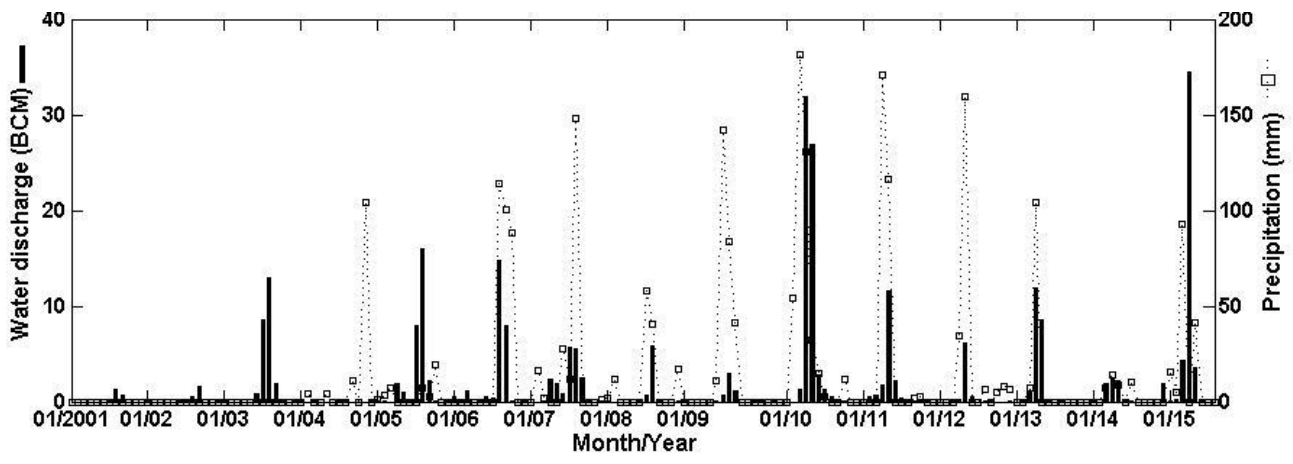

Figure 3. Monthly Water discharge below Kotri Barrage (2001-2015) and precipitation in Indus deltaic region (2004-2015)

Before the emergence of Pakistan only the Sukkur Barrage was built in 1932, but, up to now, more reservoirs were constructed, such as the Mangla on the Jehlum River and the Tarbella and Chashma on the Indus River, with a total storage capacity of $20 \mathrm{MAF}$ (24.66 BCM) (Memon, 2004). Presently, this system comprises 3 major dams, 23 barrages, 12 inter-river canals, 48 perennial canals with a running length of $60,000 \mathrm{~km}$ and about

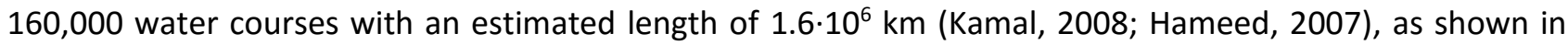
Figure 4. 


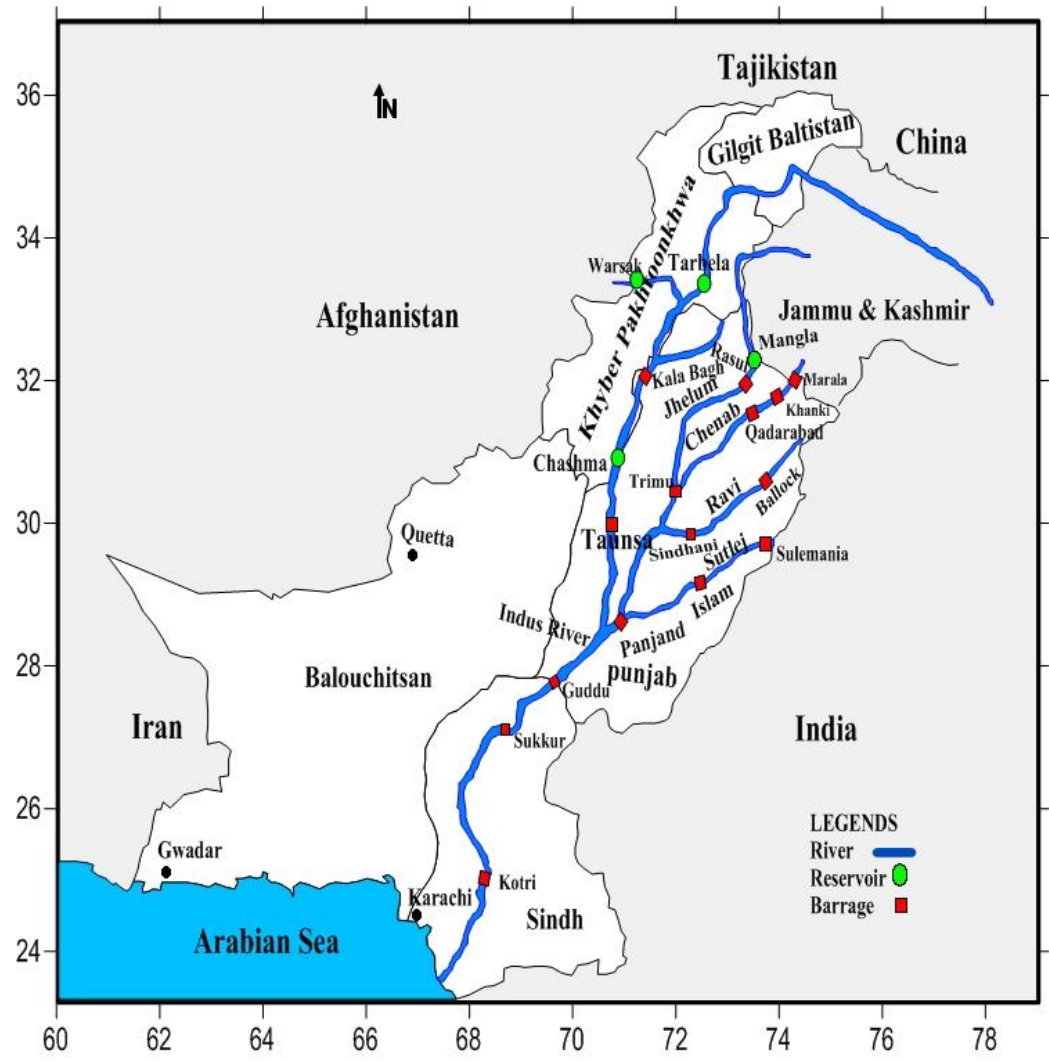

Figure 4. The Indus river basin; major rivers, reservoirs and barrages

This vast irrigation system feeds more than 17.3 million hectares (Mha) of irrigated land in Pakistan (Rizvi, 2001). The provision of irrigation water for agricultural activities in the upper and middle Indus basin through hydraulic constructions for hydroelectric power and irrigation resulted in the reduction of water discharge into the lower Indus basin to crises levels. Therefore, there is inadequate flow below the Kotri Barrage to maintain the natural ecosystems of the Indus Delta. Figure 5 shows the current status of devastation in the downstream parts of IRE.

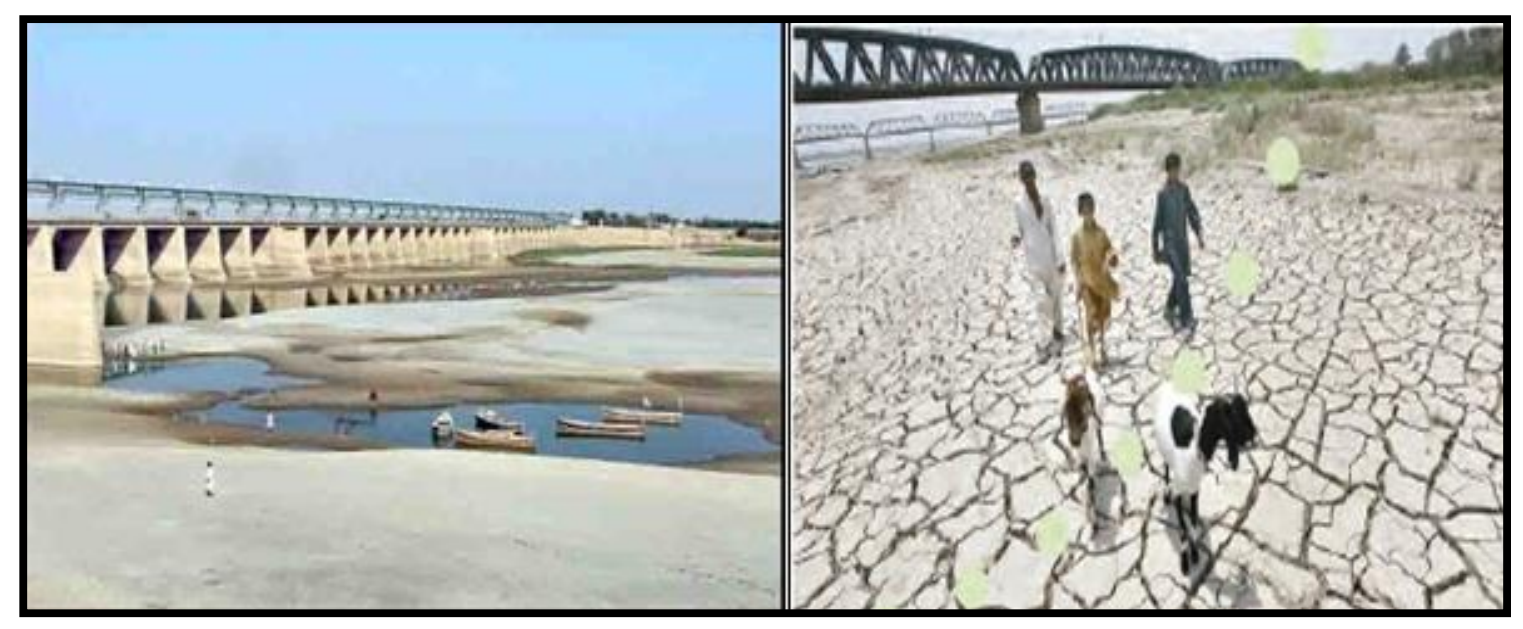

Figure 5. A view of the dry Indus Delta below the Kotri Barrage 


\subsection{Water logging}

The construction of vast irrigation systems on the Indus basin has also created large-scale water logging and salinity problems that have resulted in a rapid increase in the ground water table due to the combined effects of high water abstraction from the aquifer and seawater intrusion. As a consequence 2.93 Mha and 6.18 Mha of land have been badly affected with water logging and salinity, respectively.

It has been reported that about 150 million tons of salt are added annually to the soil-matrix, while about 80 million tons are removed through leaching; thus each acre accumulates about 0.6 ton of additional salt every year (Kahlown et al., 2002).

It has been assessed that 1.275 million acres of land in three districts, namely Nawabshah, Sanghar and Mirpurkhas, on the left bank of the Indus River (Sindh Province) have been affected by water logging after the construction of the Sukkur and Kotri barrages (Alagha et al., 2011; Dan Marsh, 1997). According to an Interim Report of the Asian Development Bank (2005), soil salinity in the Sindh Province has been responsible for a $40-60 \%$ reduction of major crop production in recent years.

To reduce the threats of rising ground water and the associated problem of water logging and salinity, a network of drainage canals were constructed to drain saline ground water into the Arabian Sea. Among them, the Left Bank Outfall Drain, a man made drainage system on the left bank of Indus River in Sindh Province, remained most criticized project, because of its failure to drain the saline ground water into the Arabian Sea. Conversely, it left a negative impact and became the cause of further destruction of agricultural lands in lower Sindh. According to Memon (2004) 567,000 ha of land were lost to the sea, because tidal link increased the coastal inundation trends. In general the drainage system had adverse results from the desired ones.

\subsection{Sea water intrusion}

A longitudinal profile of salinity distribution was recorded during the wet and dry seasons in the IRE. During the wet season salinity varied from 0.18 to 13.3 at the surface, whereas salinity ranged between $0.24-17.34$ near the bottom. Maximum (17.34) and minimum (0.18) salinity values were observed at the mouth and at $24 \mathrm{~km}$ upstream, respectively, while salinity was absent at all other stations further upstream that were controlled by river runoff, as shown in Figure 6a. The vertical distribution of salinity along the cross-section also showed a partial stratification in the estuary. On the other hand, during the dry season, river discharge was negligible; hence salt water penetrated a longer distance upstream, which formed a strong salt wedge (stratification) in the estuary. The minimum value for salinity (0.25) was observed at $84 \mathrm{~km}$ upstream, while maximum salinity (36.2) was recorded at the mouth, as shown in Figure 6b.

SSC data also showed significant seasonal variations, which was mainly influence by river discharge. As shown in Figure 7a, during the wet season SSC varied from 439 to $758.42 \mathrm{ppm}$ at the surface, while it ranged between 514.7-908.24 ppm near the bed. Meanwhile, maximum (908.24 ppm) and minimum (439 ppm) SSCs were observed at 16 and $95 \mathrm{~km}$ upstream, respectively, which indicates that sediment was transported by the flood from the upstream towards the estuary. On the other hand, during the dry season river discharge was negligible and less sediment was transported by the flow from the upstream areas, hence, SSC values were much lower. The minimum value (19.4 ppm) was observed at $95 \mathrm{~km}$ upstream, while maximum SSCs (95.55 $\mathrm{ppm}$ ) were recorded at $24 \mathrm{~km}$ upstream, as shown in Figure $7 \mathrm{~b}$.

Both observed salinity and SSC data show that the fresh water discharge meets the saline seawater near the mouth of Indus delta during the wet season and sediment transported by the river flow from the upstream is trapped in the estuary and forms an estuarine turbidity maximum (ETM) at about $20 \mathrm{~km}$ from the mouth; the location of the ETM coincides with the extent of saltwater intrusion inside the delta. During the dry season, since the river discharge and the associated sediment input from the upstream are insignificant, the low SSC are most likely caused by sediment resuspension by waves and/or tidal currents, transporting the ETM further upstream, about $24 \sim 28 \mathrm{~km}$ away from the mouth, where the salt wedge presents a maximum gradient. 


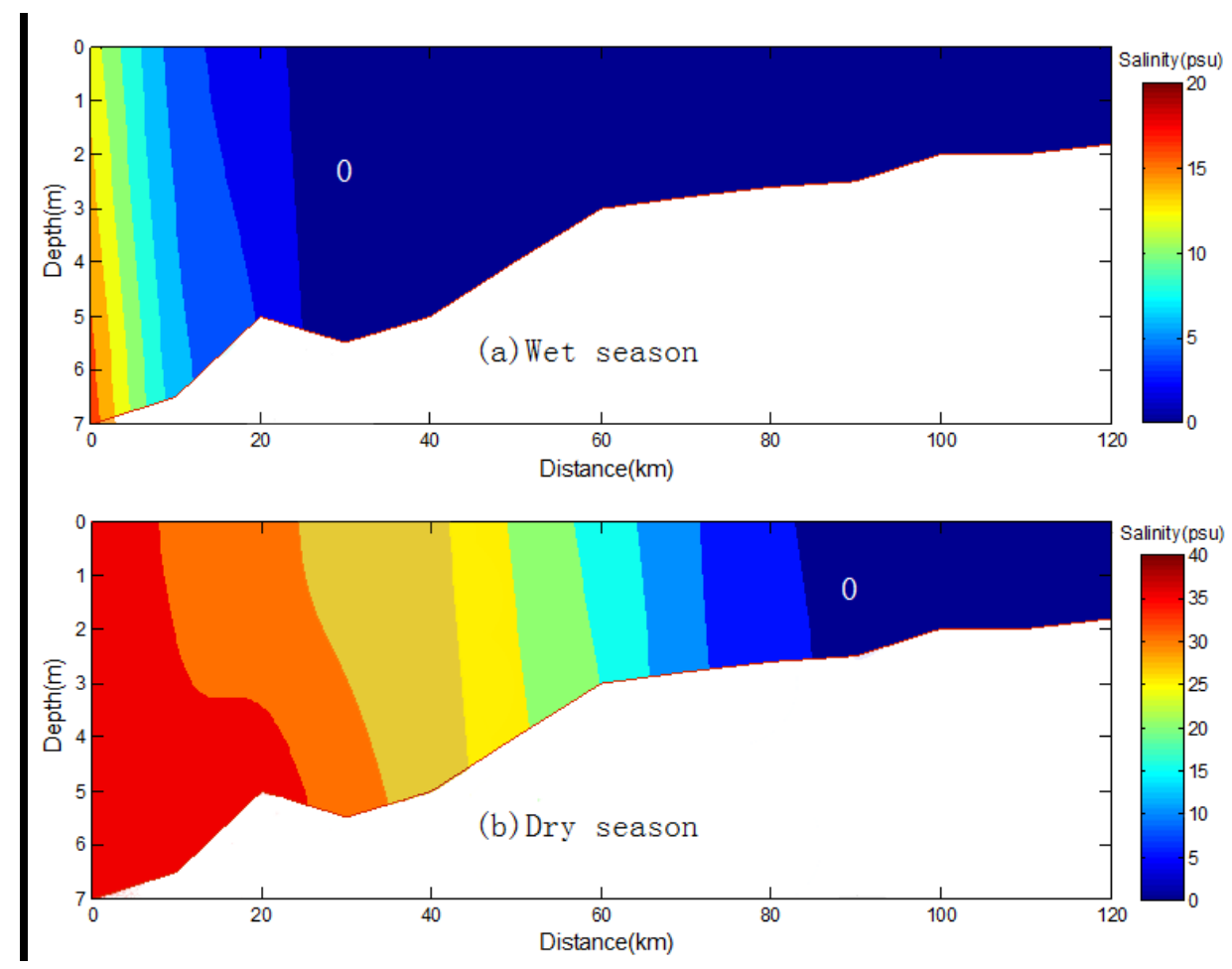

Figure 6. Longitudinal salinity distributions during, a) August, 2014 (wet season) and b) May, 2013 (dry season)
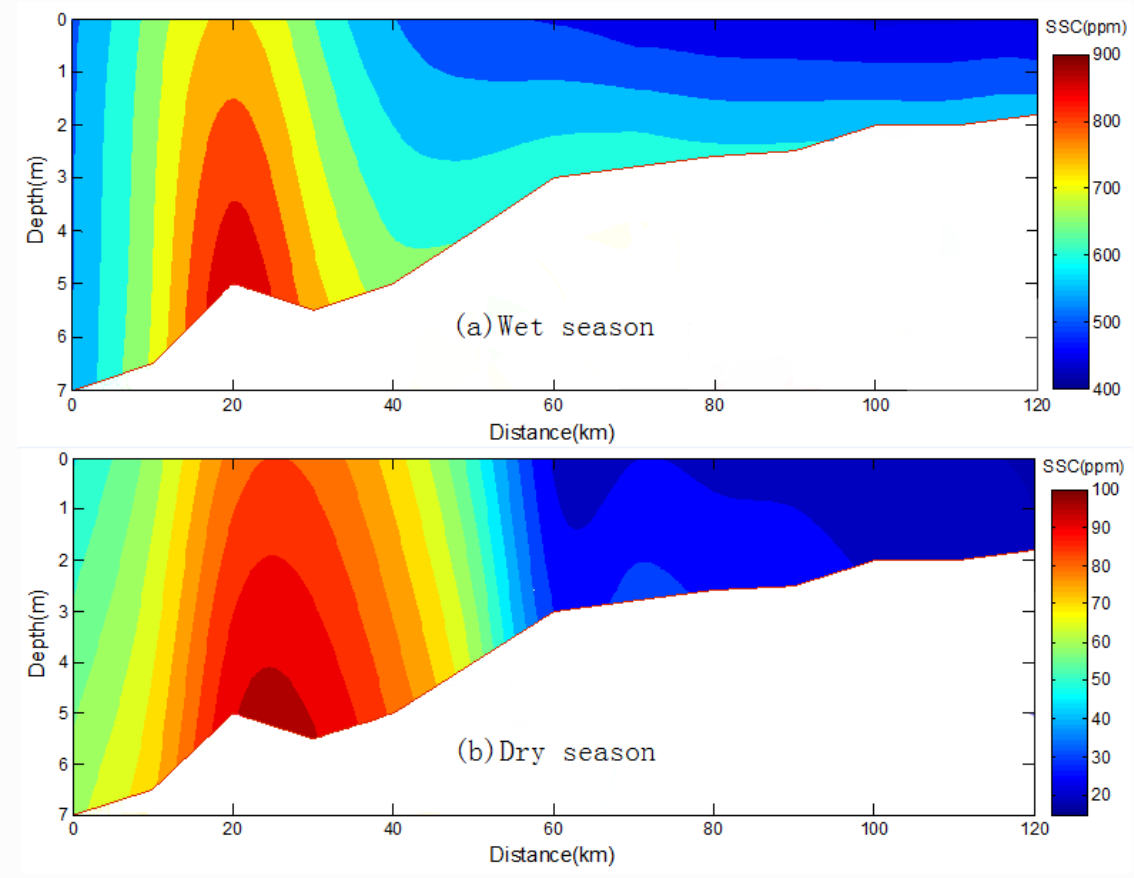

Figure 7. Longitudinal suspended sediment concentration during a) August 2014 (wet season) and b) May 2013 (dry season) 


\subsection{Coastal Erosion and Sea Encroachment}

The seawater intrusion on Pakistan's coast is also one of the causes of land erosion. Satellite images of 2004 and 2015 were compared to analyze the coastline changes and to reveal variations in erosion and accretion along the Indus Delta, as shown in Figure 9. The images clearly show that erosion and accretion occurred at different regions along the coastline in the past 10 years. More specifically, the mouth of the Indus Delta is the most highly eroded region (small rectangle in Figure 9); a very high average erosion rate of around $0.179 \pm 0.0315 \mathrm{~km}$ year ${ }^{-1}$ for the past 10 years was estimated in this region, based on the satellite data. Erosion is also observed along the main channel of Indus River.

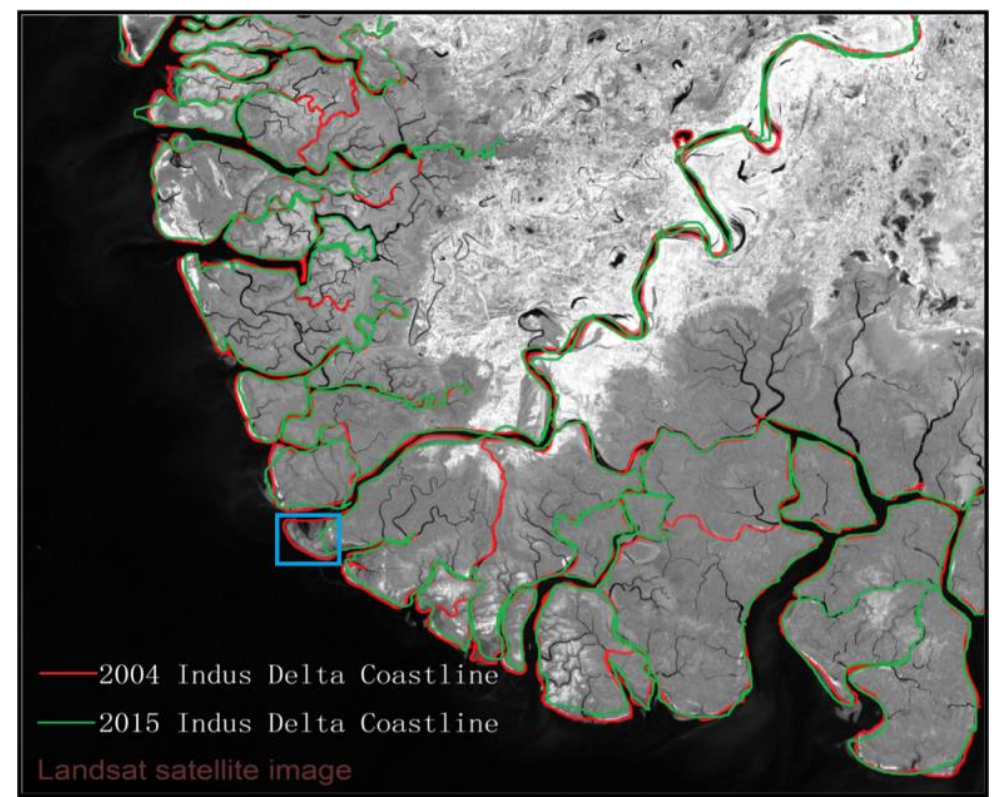

Figure 9. Changes in the Indus Delta coastline during 2004 to 2015 (red and green lines show the coastline during 2004 and 2015 respectively, data obtained from NASA)

In addition to the above, during the spring tide period, coastal flooding also supports tidal infringement over million acres of land in the Indus Delta, which results in thousands of hectares of the Badin, Sujawal and Thatta districts to be inundated by seawater. According to estimates, 0.5 million hectares of fertile land in the district of Thatta and in adjoining areas (IRIN, 2001), or about $12 \%$ of the total cultivated area of the entire Sindh province (Government of Pakistan, 2001), is now affected by coastal flooding. This corresponds to about $33 \%$ of the total area of the districts of Badin, Sujawal and Thatta, as shown in Table -1.

Table 1. Land degradation due to sea encroachment (Source: IUCN, 2003)

No
1
2
3
4
5
6
7
8

Taluka

Ghorabari

Shah Bandar

Kharochhan

Mirpur Sakro

Jati

Keti Bandar

Golarchi

Badin

\section{Area (acres)}

31,490

590,000

117,823

60,178

226,663

113,900

30,625

49,179

$1,219,858$ 


\section{Future threats and challenges}

The Indus deltaic region in the future will continue to be affected by the anthropogenic activities continuing upstream, but also by the neighboring sea in the south due to climate change and local weather conditions. According to the UNESCAP (1996), during the southwest monsoon when winds are more than 25 knots, the strong storm tides inundate the vast area of deltaic plains with saltwater.

In the past the Indus Delta was covered with 650,000 acres of the of mangrove forest, which was the fifth largest mangrove forest in the world (Forestry Sector Master Plan, 1992). It is a well-established fact that mangroves provide protection soil erosion under tropical cyclones, heavy tidal actions and tsunamis. Meanwhile, they are nursery grounds for thousands of species and are very significant for commercially important fish and shellfish species. The reductions in silt load and fresh water in the delta have stunted the growth of mangrove forest.

According to the review report of the Asian Development Bank (2005), the mangrove forest has been reduced to just 400,000 acres, of which 125,000 acres are healthy and 125,000 acres are dying, while the remaining mangroves are in moderate condition. If the current situation persists, the mangrove forests will soon be extinct. Therefore, it is essential to regenerate these forests through artificial planting. At the same time, the sea levels worldwide have risen due to global warming from 10 to $20 \mathrm{~cm}$ during the last century and the Earth's climate has warmed by about $1^{\circ} \mathrm{C}\left(1.8^{\circ} \mathrm{F}\right)$ over the last 100 years (IPCC, 2007). It is also estimated that global mean temperatures will rise by $1^{\circ} \mathrm{C}$ above the present value by 2025 and by $3^{\circ} \mathrm{C}$ before the end of the next century (IUCN, 2003). The global mean sea level (GMSL) rose by about 1.5 to $2 \mathrm{~mm}_{\text {year }}{ }^{-1}$ during the $20^{\text {th }}$ century, but the rate at end of the century was greater than during the earlier part of the century (IPCC, 2007). GMSL rose by about $1.2 \mathrm{~mm}_{\text {year }}{ }^{-1}$ from 1901 to 1990, while the corresponding rate during 1993 to 2010 was $3 \mathrm{~mm}$ year $^{-1}$ (Hay, 2015). If this tendency continues, it is expected to have significant impacts to the Pakistani coast, since it lies in a region where increasing temperature is expected to be higher than the global average, by virtue of its geographical location.

Regarding climatic factors in the area, historical air and sea surface temperatures (SST) data of Karachi also show increasing trends over the past 35 years, of the order of $0.19^{\circ} \mathrm{C}$ and $0.3^{\circ} \mathrm{C}$ per decade for air temperature and mean SST, respectively (Khan et al., 2002).

The sea level rise along the Karachi coast is $1.1 \mathrm{~mm}_{\text {year }}{ }^{-1}$, based on the recorded data in past 100 years at Karachi harbor (Quraishee, 1988). Sea level rise data, observed along the Pakistan coast, present the same increasing trend, as shown in Figure 8. If this trend continues it would result to $100 \mathrm{~mm}$ over the next century, which would have devastative impacts on the Pakistan coasts.

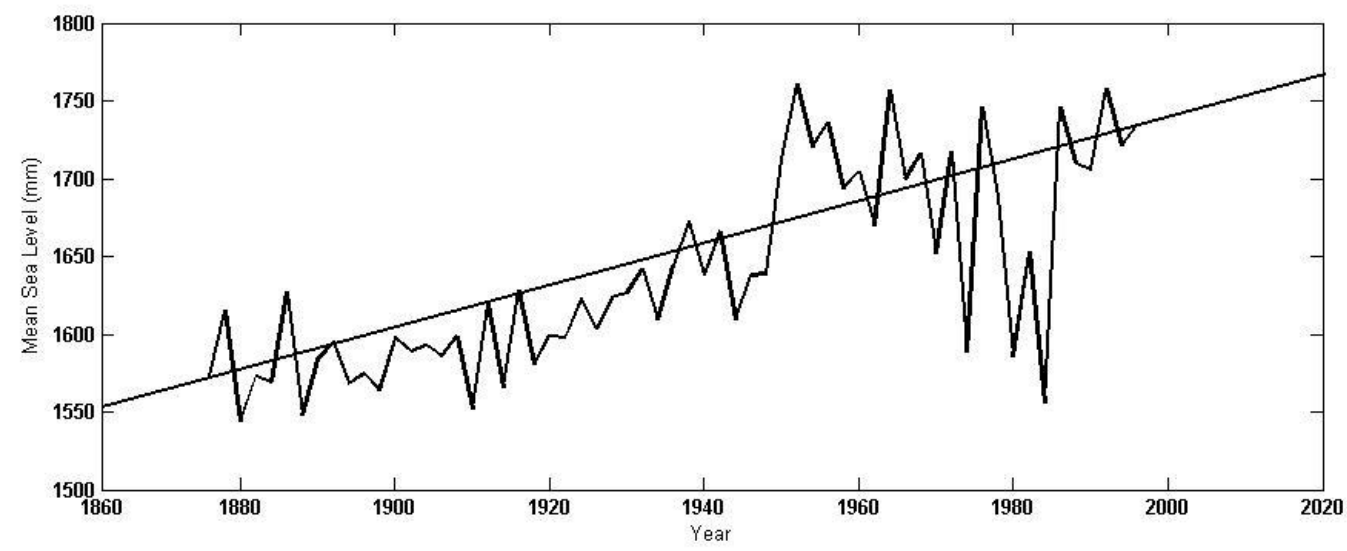

Figure 8. Annual variation of mean sea level at Karachi Harbor (modified from Quraishee, 1988) 
However, coastal erosion is one of the major, imminent, problems along the Indus delta; according to Haq (2008), by 2025, an area of $17353 \mathrm{Km}^{2}$ in the district of Thatta with 1.1 million people could have vanished at the current rate of erosion. The old port of the Sindh province, Keti Bandar, is also threatened if the erosion and intrusion continue at the present pace.

The stated current conditions and future trends ultimately raise problems for local communities, given that about 1.2 million people live around the mangrove forests at Sindh coast and 900,000 of them reside in the Indus Delta (Salman, 2002). On the other hand, salt water intrusion has already created several problems, resulting to the dispersal of local communities and their livelihoods. According to Giosan et al., (2014), saltwater-soaked soils had significant impacts on the agriculture sector along the Indus coast.

In the future, the relative impacts of marine factors on the Indus Delta coastline is expected to increase even more due to climate change; similar predictions were also made by IPCC (2014), which stated that mega-delta regions in south and southeast are at high risk due to increased flooding from the sea that and billions of people will be affected by the 2050s.

Therefore, necessity and extreme need of today is construction effective and environmentally friendly coastal protection works in the vulnerable parts of the coast to protect the area from inundation and erosion and to fulfill the minimum requirement for continuous freshwater flow in the Indus River throughout the year.

\section{Conclusions}

A thorough review of the available literature and field observational data on the Indus River and its delta has revealed that the Indus Delta was once a fertile and richly vegetated region, but it now experiences heavy degradation, caused by the abrupt reduction in river flow. The main cause of the freshwater decline is the large-scale hydraulic engineering activities in the Indus River Basin, including runoff regulation, water withdrawal for irrigation and hydroelectric power plants. Thus, river flow is irregular and is limited to only two months in the year. The decrease in water and sediment discharge below the Kotri barrage increases the effect of waves and tides, resulting in sea water intrusion and coastal erosion. It is observed that sea water intrusion can reach about $84 \mathrm{~km}$ upstream from the delta during the dry season, which not only damages the deltaic ecosystem, including mangrove forest and primary productivity in the delta, but adversely affects agricultural lands and ground water resources. The average erosion rate at the mouth is about $0.179 \pm 0.0315$ $\mathrm{km}$ year ${ }^{-1}$ during the past 10 years. Thus, sea water intrusion and coastal inundation have both caused devastating environmental and social impacts, due to which, the whole ecosystem of the Indus Delta is facing serious threat.

The Indus Delta is characterized as a complicated estuarine system under the influence of a biannual monsoonal cycle. Due to its great importance and dynamics, it is necessary to understand the mechanisms and processes of sea water intrusion and coastal inundation in the near future. However, there is a shortage of detailed field observational data. Meanwhile, few researchers have studied the Indus Delta and, to present, no modeling attempts have been conducted to evaluate the precise extent of the coastal inundation and sea water intrusion. In order to bridge this gap, there is an urgent need for a systematic and long time-series of field surveys, combined with a coastal model for the accurate estimation of onshore coastal inundation and sea water intrusion in the Indus deltaic region, so as to protect the estuarine ecosystem and to forecast precise warnings in order to minimize loss of life and property.

At present, with the development of advanced computer techniques, two-dimensional and/or threedimensional coastal ocean models have been widely used to better understand and analyze the hydrodynamics, sea water intrusion, and coastal inundation of different estuaries all over the world (Zahed et al., 2008; An et al., 2009; Zhao et al., 2009; Jeong et al., 2010; Yang et al., 2010; Yoon and Shim, 2013; Bhaskaran et al., 2014), with satisfactory results. 


\section{Acknowledgement}

The authors thank the financial support from the State Key Laboratory of Satellite Ocean Environment Dynamics, Second Institute of Oceanography of State Oceanic Administration and National Natural Science Foundation of China (No. 41376095), Natural Science Foundation of Zhejiang Province (LR16E090001), and National Institute of Oceanography of Pakistan.

\section{References}

Abbasi A.G. (2002), Restoration of Sindh's primary rights over River Indus, 18th convention of SANA, Cherry Hill, New Jersey, July, 4-7.

ADB and IUCN. (2002), Regional technical assistance for coastal and marine resources management and poverty reduction in South Asia: situation analysis report, RETA 5974-PAK, Asian Development Bank and International Union for Conservation of Nature.

ADB (2005), Sindh coastal and inland community development project, interim report, VollI, TA 4525-PAK, Asian Development Bank, 1-253.

ADB Review Report. (2005), Technical assistance to the Islamic Republic of Pakistan for preparing the Sindh coastal and inland community development project, www.pdi.org.pk,1-18.

Alagha S.K., Bhatti I., Zaqoot H.A., Khan S.H. and Ansari A.K. (2001), Physico-chemical environment of coastal areas in the vicinity of LBOD and tidal Link drain in Sindh, Pakistan after cyclone 2a, International Journal of Civil and Environmental Engineering, 3(3), 150-155.

An Q., Wu Y., Taylor and Zhao B. (2009), Influence of the Three Gorges Project on saltwater intrusion in the Yangtze River Estuary, Environmental Geology, 56(8), 1679-1686.

Bhaskaran P.K., Gayathr R., Murty P.L.N., Bonthu S.R. and Sen D. (2014), A numerical study of coastal inundation and its validation for Thane cyclone in the Bay of Bengal, Coastal Engineering, 83, 108-118.

Chu A., Wang Z.B., Vriend H.J.D. and Stive M.F.G. (2010), A Process-based Approach to Sediment Transport in the Yangtze Estuary, Coastal Engineering, 1-12.

Dan Marsh (1997), A case study of the left bank outfall drains in Pakistan. Draft working paper presented at the New Zealand, Agricultural and Resource Economics society conference, Blenheim 4-5 July.

Forestry Sector Master Plan. (1992), A comprehensive report on Sindh, Asian Development Bank and UNDP Program Pakistan.

Giosan L., James S.J., Constantinescu S. and Day J.W. (2014), Climate change: Protect the world's deltas, Sea-level rise and river engineering spell disaster, Nature, 516(7529), 1- 3.

Government of Pakistan. (2001), Economic Survey, Ministry of Finance, Islamabad.

Hameed T. (2007), Opportunities and challenges in water sector. Pakistan Development Forum 2007, Presentation as the Chairman Pakistan Water and Power Development Authority, April 27, Pakistan.

Haq R. (2008), Climate Change Likely to Flood Karachi Coastline, http://www.riazhaq.com/2008/07/climate-changelikely-to-flood-karachi.html.

Hay C. C., Morrow E., Kopp R. and Mitrovica J.X. (2015), Probabilistic reanalysis of twentieth-century sea-level rise, doi: 10.1038/nature14093, 1-12.

Hughes A.W. (1876), Gazetteer of the province of Sindh, Printed at William clowes and Sons, StamforD $8^{\text {th }}$ street AKD ciiarivo Cross. p.600. https://archive.org/details/agazetteerprovi00unkngoog

Inam A., Clift P.D., Giosan L., Tabrez A.R., Tahir M., Rabbani M.M. and Danish M. (2007), The geographic, geological and oceanographic setting of the Indus River, Large Rivers: Geomorphology and management, edited by A Gupta, John Wiley \& Sons, Ltd. 333-346.

IPCC, Asia in Climate Change. (2007), Impacts, adaptation and vulnerability. Contribution of working group II to the fourth assessment report of the intergovernmental panel on climate change, Cambridge: Cambridge University Press, 469-506. 
IPCC. (2014), Intergovernmental panel on climate change (IPCC) fifth assessment, working group 2 report.

IRIN. (2001), Pakistan: Intruding sea water threatens Indus River, UN Office for the co-ordination of humanitarian affairs integrated regional information networks article, December 31.

IUCN. (2003), Environmental degradation and impacts on livelihoods sea intrusion, - A case study, IUCN Pakistan, 1-77.

Jeong S., Yeon K., Hur Y. and Oh K. (2010), Salinity intrusion characteristics analysis using EFDC model in the downstream of Geum River, Journal of Environmental Sciences, 22(6), 934-939.

Kahlown M.A., Azam M., Blackwell J. (2002), Prospects of sequential biological concentration for salinity- management in Pakistan, Quarterly Science Vision, 8(1), 79-86.

Kamal A. (2008), Environmental flows Indus river system in Pakistan, $3^{\text {rd }}$ International conference on water resources and arid environments and the $1^{\text {st }}$ Arab Water Forum Riyadh, Saudi Arabia.

Khan T.M.A., Razzak D.A., Chaudry Q.Z., Qadir D.A., Kabir A. and Sarker M.A. (2002), Sea level variations and geomorphological changes in the coastal belt of Pakistan, Marine Geodesy, 25, 159-174.

Memon A.A. (2004), Evaluation of impacts on the lower Indus River basin due to upstream water storage and diversion, proceedings, World water \&environmental resources congress, ASCE-EWRI, Salt lake city, Utah, June 27 - July 1.

Meynell P. and Qureshi T. (1993), Sustainable management of mangroves in the Indus delta, Pakistan, towards the wise use of wetlands, in David, T. (Ed.), Ramsar Bureau, Gland, 113-22.

Milliman J.D., Rutkowski, Ch., and Meybeck, M. (1995), River discharge to the sea. A global river index (GLORI), LOICZ reports and studies.

Mirovoi vodnyi balans i vodnye resursy zemli. (1974), World water balance and water resources of the Earth, Leningrad, Gidrometeoizdat.

Nasir S.M.and Akbar G. (2012), Effect of river Indus flow on low riparian ecosystems of Sindh, a review paper, Rec. Zool. Surv. Pakistan, 21, 86-89.

Quraishee G.S. (1988), Global Warming and Rise in Sea Level in the South Asian Seas Region, in the Implication of Climatic Changes and the impact of rise in Sea level in the South Asian Seas Region, p.1-21.

Rizvi M. (2001), Forecasting water flows in Pakistan's Indus River, The International Development Research Center, http://idrc.ca/en/ev-5441-201-1-DO TOPIC.html.

Salman A. (2002), Draft Proposal for Economic Valuation of Mangrove Ecosystem in Pakistan, Prepared for South Asia Network for Development and Environmental Economics, Kathmandu.

UNESCAP. 1996. Coastal Environmental Management Plan for Pakistan. NewYork, 1-233

Wells J.T. and Coleman J.M. (1984), Deltaic morphology and sedimentology with special reference to the Indus River delta. In: Haq BU, Milliman JD (Eds.). Marine geology and oceanography of Arabian sea and coastal Pakistan, Van Nostrand Reinhold Company, New York, 85-100

Yang Z., Sobocinski K.L., Heatwole D., Khangaonkar T., Thom R. and Fuller R. (2010), Hydrodynamic and ecological assessment of nearshore restoration: A modeling study, Ecological Modelling, 221(7), 1043-1053.

Yoon J.J. and Shim J.S. (2013), Estimation of storm surge inundation and hazard mapping for the southern coast of Korea. Proceedings 12th International Coastal Symposium (Plymouth, England), Journal of Coastal Research, Special Issue No. 65, 856-861.

Zahed F., Etemad-Shahidi A. and Jabbari E. (2008), Modeling of salinity intrusion under different hydrological conditions in the Arvand River Estuary, Canadian Journal of Civil Engineering, 35(12), 1476-1480.

Zhao R., Yang Z.F., Sun T., Chen B and Chen B.Q. (2009), Freshwater inflow requirements for the protection of the critical habitat and the drinking water sources in the Yangtze River Estuary, China, Communications in Nonlinear Science and Numerical Simulation, 14(5), 2507-2518. 